\title{
Formulation of nimesulide-loaded polylactide/poly(lactic-co-glycolic acid) nanoparticles and the evaluation of release kinetics
}

\author{
Aneta Pobudkowska ${ }^{1), *)}$, Kamil Nosol ${ }^{1)}$, Paweł Gierycz ${ }^{2)}$, Urszula Domańska ${ }^{3), 4)}$ \\ DOI: dx.doi.org/10.14314/polimery.2018.9.2
}

\begin{abstract}
Polymeric nanoparticles containing nimesulide (NIM) were prepared by the emulsion solvent evaporation method. Biodegradable polymers were used as materials for nanoparticle formulations with the application of studies for the drug delivery sector in mind. Two analytical methods, scanning electron microscopy (SEM) and particle size analysis, were applied to investigate the obtained nanoparticles. Characteristic parameters were calculated to describe the amount of active pharmaceutical ingredient trapped in nanoparticles. The biological active substance release process was investigated under different conditions. The impact of various parameters [kind of polymer (PLA or PLGA), speed of mixing and especially of $\mathrm{pH}$ ] is presented across our research.
\end{abstract}

Keywords: nimesulide, nanoparticles, polylactide, poly(lactic-co-glycolic acid), poly(vinyl alcohol), drug release.

\section{Formulacja nanocząstek polilaktyd/poli(kwas mlekowy-co-glikolowy) z nimesulidem oraz ocena kinetyki ich uwalniania}

\begin{abstract}
Streszczenie: Polimerowe nanocząstki zawierające nimesulid (NIM) otrzymano metodą emulsyjną z odparowaniem rozpuszczalnika. Do ich wytworzenia wykorzystano biodegradowalne polimery. Wytworzone nanocząstki zbadano za pomocą skaningowej mikroskopii elektronowej (SEM) oraz analizatora wielkości cząstek. Obliczono charakterystyczne parametry opisujące ilość substancji farmaceutycznie aktywnej uwięzionej wewnątrz nanocząstek. Oceniono wpływ rodzaju polimeru stosowanego do kapsułkowania, szybkości mieszania suspensji, w szczególności pH środowiska na proces uwalniania substancji biologicznie czynnej.
\end{abstract}

Słowa kluczowe: nimesulid, nanocząstki, polilaktyd, poli(kwas mlekowy-co-glikolowy), poli(alkohol winylowy), uwalnianie leku.

Nowadays, nanotechnology is one of the fastest developing fields of science, and involved in many different scientific areas. Plenty of research has already found applications in various fields to enhance the quality of life of human beings. The implementation of nanotechnology in pharmacy and medicine is constant with investment in delivery systems composed of synthetic poly-

\footnotetext{
1) Warsaw University of Technology, Faculty of Chemistry, Department of Physical Chemistry, Noakowskiego 3, 00-664 Warsaw, Poland.

2) Warsaw University of Technology, Faculty of Chemical and Process Engineering, Waryńskiego 1, 00-645 Warsaw, Poland.

3) Industrial Chemistry Research Institute, Rydygiera 8, 01-793 Warsaw, Poland.

4) University of KwaZulu-Natal, Thermodynamic Research Unit, School of Engineering, Howard College Campus, King George V Avenue, Durban 4041, South Africa.

*) Author for correspondence; e-mail: pobudka@ch.pw.edu.pl
}

mers, biopolymers and their commonly used derivatives [1]. New possibilities for medicine opened due to all applications of (bio)polymers to construct new therapeutic systems. This phenomenon brings advantages in the fight against illnesses that are hard to be treated with known, classic methods [2]. Currently, nanotechnology is also widely used in medicine for diagnostics and tissue engineering [3]. The main goal of nano-diagnostics consists of the formulation and creation of methods enabling rapid illness diagnostics based on useful nanostructures such as: drug carriers (polymers, biopolymers, nanotubes, fullerenes, liposomes, etc.) or materials allowing highly selective particle transport (nanopores) [4]. The pharmacokinetics of commercially available pharmaceuticals and the application of nanotechnology for bioavailability enhancement can be both the foundation for further drug delivery systems [5]. The possibility of physical and chemical property changes of drugs can be obtained by use of its nanostructured forms instead 
of macrostructures. Such a modified drug can be more stable, as well as more precisely delivered to the proper place inside the body, and much better absorbed [6]. Afterwards, a controlled and verified method of active ingredient release, trapped in nanostructured drug carrier, can ensure a local concentration in the frame of the therapeutic window [7]. The use of such designed nanostructures allows also for the reduction of drug doses, which both decreases the therapy costs and limits undesirable effects.

As an active ingredient, the popular arylsulfonamide derivative drug, nimesulide (NIM) was proposed. Nimesulide belongs to the nonsteroidal anti-inflammatory drug class (NSAIDs). It inhibits the conversion of arachidonic acid to pro-inflammatory prostaglandins inside the human body by selective binding to the enzyme prostaglandin-endoperoxide synthase 2 (COX-2), causing its inactivation [8]. NIM is quickly and well absorbed by the digestive system, but it is also highly metabolized by cytochrome P450 inside the human liver, wherefore maintaining its concentration in therapeutic window plays an important role for nanostructure applications. Its pain-relieving effect starts $15 \mathrm{~min}$ after oral application and it is used in the case of many pain symptoms [9]. NIM has already been the subject of research from the emulsions and solid nanostructures field of science [10-19]. Nimesulide-loaded nanoparticles have been formulated in two types of microemulsion: Epikuron 170 (E170)/isopropyl myristate/water/n-butanol (or isopropanol) [10]. The authors presented the size of nanoparticles in the two microemulsions between 45 and $60 \AA$ to be independent of the factor $R$ ([water]/[E170]) [10]. Because of that, and the fact that nanoparticles were instantaneously formed and stayed stable during several months, the authors assumed a thermodynamic stabilization of the nanoparticles with the surfactant [10]. A microemulsion of solid nimesulide-loaded nanoparticles was obtained by the same authors in direct precipitation in two water/oil (W/O) microemulsion systems: E170 (which is a lecithin)/isopropyl myristate/water/n-butanol (ME1) and E170/isopropyl myristate/water/isopropanol (ME2) [11].

The influence of surfactant-coated, NIM-free, and NIM-loaded ethylcellulose/methylcellulose (EC/MC) nanoparticles prepared with varied drug concentrations, polymer concentrations, and surfactant concentrations were presented as well [10]. Nanoparticles were characterized by scanning electron microscopy (SEM), particle size analysis (AFM), and Fourier transform infrared spectroscopy (FT-IR). The nanoparticles mean size diameter ranged from 244 to $1056 \mathrm{~nm}$ and from 1065 to $1710 \mathrm{~nm}$ for EC and MC nanoparticles, respectively [12]. The authors showed a linear relationship between the drug concentration and loading efficiency of the nanoparticles, whose definition has also been described here in Equation (1) (see further text). The encapsulation efficiency of active ingredient-loaded nanoparticles varied between $32.8 \%$ and $64.9 \%$ [12]. The NIM and shea butter lipid nanoparticles, using a new very simple technique of preparation, were presented at pH 6.9 [13]. Lipid nanoparticles were prepared by melting shea butter and mixing with an aqueous phase using a high shear mixer. Shea butter is a natural lipid obtained from the Butyrospermum parkii seeds and is mostly composed of oleic and stearic acids. The obtained nanoparticles had a size of $90 \mathrm{~nm}$ and a narrow polydispersity (0.21). Active ingredient release was evaluated using dialysis. The nanoparticles presented in in vivo experiments possessed significant pharmacological effects that were not seen for free drug administration [13].

The nanoparticles developed from NIM and poly(lactic-co-glycolic acid) (PLGA) were presented as a biodegradable polymeric active drug carrier to treat rheumatoid arthritis [14]. Two different nonionic surfactants, vitamin E $\mathrm{d}$ - $\alpha$-tocopheryl polyethylene glycol 1000 succinate (vitamin E, TPGS) and poly(vinyl alcohol) (PVA) were used in this work [14]. The impact of surfactant percentage and ratio of active ingredient/polymer $(1 / 10,1 / 15,1 / 20)$ of the NIM-loaded structures were investigated by measurements of: the encapsulation efficiency, the particle size, the polydispersity index, and the surface charge [14]. Nanoparticles containing NIM were prepared and characterized, and the antiproliferative effect of active ingredient-loaded versus active ingredient-free on HT-29 and SW-480 cell lines was evaluated. The colloidal mixtures with nanoparticles in size ranging from 85 to $132 \mathrm{~nm}$ and negative zeta potential values were obtained. Moreover, these systems showed a good loading capacity and drug release profile, and an in vitro antitumor activity comparable to a non-loaded one [15]. The novel poly(ethyleneglycol)-block-poly(e-caprolactone) (PEG- $b$-PCL) nano-sized particles encapsulated with NIM, a selective COX-2 inhibitor, were prepared to evaluate its anticancer activity against MCF-7 breast cancer cells [16]. These NIM-encapsulated PEG- $b$-PCL nanoparticles were fabricated using three different production techniques: (i) by emulsion-solvent evaporation using a high shear homogenizer, (ii) by emulsion-solvent evaporation using an ultrasonicator, and (iii) by nanoprecipitation [16]. The nanoparticles were found to be of spherical shape with the average diameter of all nanoparticles ranging between 148.5 and $307.2 \mathrm{~nm}$. In vitro release profiles showed that all nanoparticles exhibited a biphasic release pattern. NIM-loaded nanoparticles demonstrated significant anticancer activity against MCF-7 breast cancer cells in a dose-dependent manner, which was dependent on the preparation techniques [16]. An interesting review of nanosizing techniques as important tools for improving the bioavailability of water insoluble drugs was recently presented. In this review, strategies including drug nanocrystals, nanoemulsions, nanosuspension and polymeric micelles were reviewed [17]. The development of polymeric nanoparticles for the delivery of JSI-124 (a small molecule inhibitor of STAT3) to tumor and immunosuppressed dendritic cells (DCs) using poly(D,L-lactic-co-glycolic acid) nanoparticles (PLGA) us- 
ing the emulsification solvent evaporation method was presented as a potential anticancer modulation composition [18]. A similar invention proposed NIM-loaded nanoparticle compositions with at least one surface stabilizer adsorbed on, or associated with, the surface of the NIM-loaded particles. The obtained effective average particle size was less than $2000 \mathrm{~nm}$ [19]. Thus, the intravenous administration of loaded nanoparticles-based drug can potentially enhance the time of circulation in blood and improve drug performance by inducing the accumulation into tumors by enhanced permeability and retention.

In this paper, the formulation of NIM-loaded nanoparticles with PLA or PLGA compositions, and the determination of two ways of release from nanostructures at constant temperature and different $\mathrm{pH}$ and speed of shaking ( $\mathrm{rpm}$ ) were investigated. The quantitative release phenomenon is an important issue concerned with drug effectiveness. The goal of the research was to understand whether the type of used polymer (PLA or PLGA), thus nanoparticles shape, correlates with the nimesulide release characteristics, and whether both drug release methods can be applied to in vitro experiments. Moreover, the chosen $\mathrm{pH}$ conditions to investigate release process correspond to each part of human digestion system, which is crucial for drug delivery system design.

\section{EXPERIMENTAL PART}

\section{Materials}

- Nimesulide (CAS Registry No. 51803-78-2, $\geq 0.98$ mass fraction purity), poly(D,L-lactide), PLA, (CAS Registry No. 26680-10-4, R 203S, Mw = 18-28 $\left.\cdot 10^{3} \mathrm{~g} / \mathrm{mol}\right)$, poly(D,L-lac- tide-co-glycolide), PLGA, (CAS Registry No. 26780-50-7, $\mathrm{R} 203 \mathrm{~S}, M w=54-69 \cdot 10^{3} \mathrm{~g} / \mathrm{mol}$ ) were delivered by Sigma Aldrich.

- Poly(vinyl alcohol), PVA, (CAS Registry No. 9002-89-5, $M w=88 \cdot 10^{3} \mathrm{~g} / \mathrm{mol}, 88 \%$ hydrolyzed) was delivered by Acros Organics.

The names, abbreviations, structures, and molecular weights of the compounds are given in Table 1.

- The buffers were prepared from compounds delivered by $\mathrm{POCH}$, i.e., dipotassium hydrogen phosphate (CAS number 7758-11-4, 0.99 mass fraction), potassium dihydrogen phosphate (CAS number 7778-77-0, 0.995 mass fraction), potassium hydroxide (CAS number 1310-58-3, 0.988 mass fraction), phosphoric acid (CAS number 7664-38-2, 0.85 mass fraction).

- For organic solvents, we used methylene chloride (CAS number 75-09-2, 0.99 mass fraction), dimethyl sulfoxide (CAS number 67-68-5, 0.99 mass fraction), acetone (CAS number 67-64-1, 0.999 mass fraction). For chromatographic measurements, we used methanol (CAS number 67-56-1, 0.99 mass fraction). All solvents were purchased from Sigma Aldrich. Twice distilled and degassed water, deionized and filtered with MiliporeElix 3 was used. Cellulose dialysis bags with a pore size of $12 \mathrm{kDa}$ (avg. flat width $25 \mathrm{~mm}, 1.0$ in.) were obtained from Sigma Aldrich.

\section{Particle preparation}

The nanoparticles formulation was based on an "oil in water" $(\mathrm{O} / \mathrm{W})$ emulsion. In our case, oil means an organic solvent. Poly(vinyl alcohol) (PVA) dissolved in water works as an emulsion stabilizer surrounding organic ("oil") droplets. The concentration of PVA in water should not be lower than $0.4 \%$ but not higher than $3.0 \%$ (in our case

T a b l e 1. Characteristics of the investigated compounds

\begin{tabular}{c|c|c}
\hline Name of compound/abbreviation & Molecular weight, g/mol \\
\hline Nimesulide/NIM & Structural formula & 308.31 \\
Poly(D,L-lactide)/PLA & $18-28 \cdot 10^{3}$ \\
Poly(D,L-lactide-co-glycolide)/PLGA & $54-69 \cdot 10^{3}$ & $88 \cdot 10^{3}$ \\
\hline
\end{tabular}


$0.8 \mathrm{~g}$ PVA was dissolved in $100 \mathrm{~cm}^{3}$ of water). This mixture was mixed for $24 \mathrm{~h}$ until a homogenous solution was obtained and then filtered to remove undissolved parts. In the second beaker, $15 \mathrm{mg}$ of selected active ingredient, NIM, was added to $30 \mathrm{~cm}^{3}$ of acetone and $30 \mathrm{mg}$ of the proper polymer. The scheme of the preparation is given in Fig. 1.

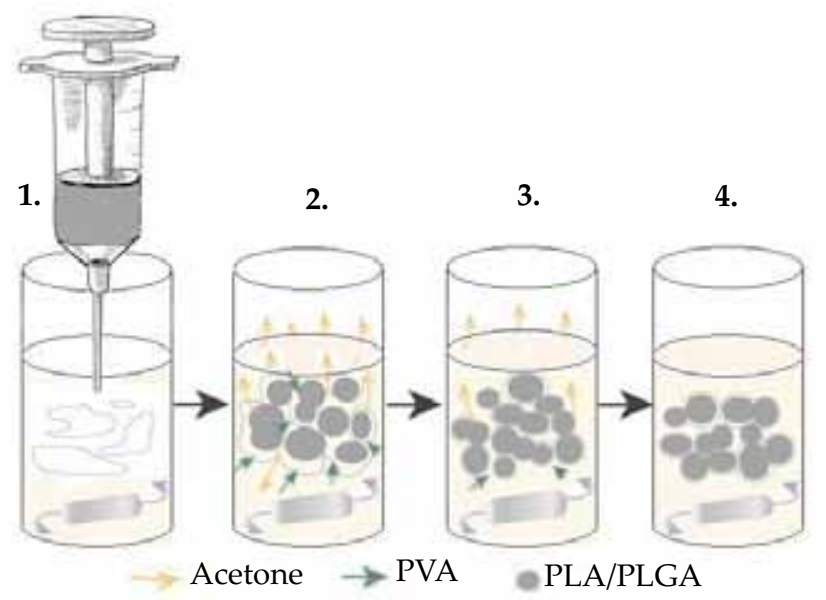

Fig. 1. The scheme of the preparation of nanoparticles

The prepared organic solution from the first step was injected to a continuously stirred aqueous solution of PVA. Emulsion droplets were quickly formed in the whole beaker volume. The droplets started to be covered with PVA, which caused a reduction in affinity between acetone and the polymer fraction. The locally increased acetone concentration near the drops caused floculation of the PVA and reduced its affinity to acetone. Afterwards, acetone started to evaporate and the droplet diameters gradually decreased (step 2). Evaporation of acetone reduced the PLA/PLGA solubility (step 3) and determined the formation of nanoparticles loaded with the active ingredient (step 4). The time needed for the entire evaporation of acetone was about $24 \mathrm{~h}$.

\section{Methods used for drug release}

Two methods for NIM release from the polymer nanoparticles were used: the dialysis membrane method (DM) and a high throughput screening method (HTS). In the case of the DM method, a $1 \mathrm{~cm}^{3}$ sample of nanoparticle suspension was washed three times with distilled water and centrifuged (Hettichzentrifugen, EBA 20). Then, $1 \mathrm{~cm}^{3}$ of proper buffer ( $\mathrm{pH} 2.5$ or 7.4 or 9.0) was added and the sample was introduced to a dialysis sack with a pore size of $12 \mathrm{kDa}$. The sack was placed into a vessel containing $150 \mathrm{~cm}^{3}$ of $10 \mathrm{mM}$ buffer with the proper $\mathrm{pH}$. Afterwards, the system was closed and slowly mixed with a magnetic stirrer. Samples of a volume of $0.2 \mathrm{~cm}^{3}$ were collected at equal time intervals.

In the HTS method, similarly to the DM method, $1 \mathrm{~cm}^{3}$ samples of nanoparticles were washed three times with distilled water and centrifuged (Hettichzentrifugen, EBA 20). Then, $1 \mathrm{~cm}^{3}$ of the proper buffer ( $\mathrm{pH} 2.5,7.4$ or 9.0) was added and the solution was shaken. A further $0.2 \mathrm{~cm}^{3}$ of obtained suspension was placed in the well of the donor plate with filter mode on the bottom (dialysis sack). In this way, ca. $0.5 \mathrm{mg}$ of nanoparticles was loaded to each well. Then, to limit evaporation, the donor well-plate was closed with self-adhesive foil. Next, $0.28 \mathrm{~cm}^{3}$ of the proper buffer ( $\mathrm{pH} 2.5$ or 7.4 or 9.0) was placed in the wells of the acceptor plate. Finally, both donor and acceptor plates were put together and shaken (Unipan, laboratory shaker type 358 S) for $12 \mathrm{~h}$ or longer. After the proper incubation times, samples were collected and analyzed chromatographically.

\section{Methods of testing}

- Particle sizes were determined by photon correlation spectroscopy using a Zetasizer 3000 HS (Malvern UK). Samples were diluted with water just after production and their size established by taking the average of at least three measurements.

- Scanning electron microscopy (SEM) was used to characterize the morphology of the nanoparticles. Samples were diluted in distilled water, dried, covered by a fine gold layer (11.6 nm thick) with a Leica EM SCD 500 coater $(20 \mathrm{~s}, 44 \mathrm{~mA})$, and observed on a JSM-6300 (JEOL, Tokyo, Japan) scanning electron microscope.

- The efficiency of the used method for particle preparations was described by two parameters:

loading efficiency $(L E)$ - defining the percentage of the active ingredient in the obtained nanoparticles structure:

$$
L E=\left(\frac{m_{\mathrm{d}}}{m_{\mathrm{n}}}\right) \cdot 100 \%
$$

where: $m_{\mathrm{d}}-$ mass of loaded active pharmaceutical ingredient, $m_{\mathrm{n}}$ - mass of loaded nanoparticle;

entrapment efficiency $(E E)$ - efficiency of the nanoparticles formulation:

$$
E E=\left(\frac{\frac{L E}{100} \cdot m_{\mathrm{dup}}}{m_{\mathrm{du}}}\right) \cdot 100 \%
$$

where: $m_{\mathrm{du}}$ - mass of active ingredient used for nanoparticle preparation, $m_{\text {dup }}$ - the sum of $m_{\mathrm{du}}$ and of polymer used for the nanoparticle preparation.

The necessary mass data was obtained by the following experimental procedure. A sample was collected from the nanoparticles suspension. Then, it was centrifuged (Hettichzentrifugen, EBA 20). The supernatant above the pellet was removed and the nanoparticles were washed three times with distilled water and further dried under vacuum. A known mass of dried nanoparticles was dissolved in a $2 \%$ solution of DMSO in acetonitrile until the entire polymer dissolved. The mass of active substance loaded in the nanoparticles was determined by the use of HPLC (high-performance liquid chromatography, Agilent Tech- 
T a b l e 2. Assessment of nanoparticles

\begin{tabular}{c|c|c}
\hline Polymer & $\begin{array}{c}E E \\
\%\end{array}$ & $\begin{array}{c}L E \\
\%\end{array}$ \\
\hline PLA & 69.3 & 23.1 \\
PLGA & 84.6 & 28.2 \\
\hline
\end{tabular}

nologies 1200 series with UV-VIS detector and C18 column $150 \times 4.6 \mathrm{~mm}, 5 \mu \mathrm{m}$ filling), gradient methanol (75\%) and phosphate buffer $(25 \%)$, flow $1 \mathrm{~cm}^{3} / \mathrm{min}$. The values of the calculated parameters are given in Table 2 .

The results clearly show that high efficiency of nanoparticles formation has been obtained for both polymers.

\section{RESULTS AND DISCUSSION}

Biodegradable polymers used in controlled drug delivery formulations must be chemically inert, non-toxic and free of leachable impurities. Degradation products must be tolerated with little or no adverse reactions within the biological environment and should be metabolized and removed from the body via normal metabolic pathways. Therefore, the biodegradable polymers

a)

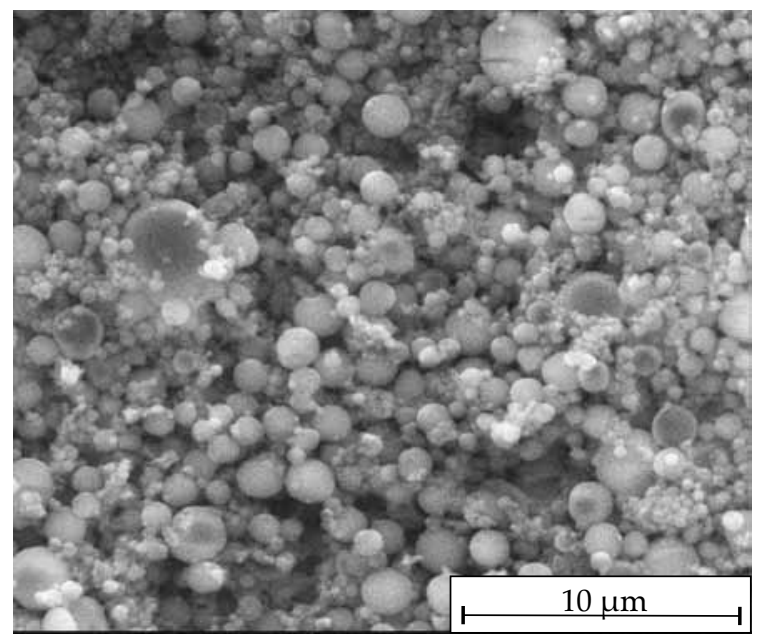

T a b l e 3. Characteristics of the obtained nanoparticles

\begin{tabular}{c|c|c|c}
\hline Polymer & $\begin{array}{c}\text { Average size } \\
\mathrm{nm}\end{array}$ & $\begin{array}{c}\text { Zeta } \\
\mathrm{mV}\end{array}$ & $\begin{array}{c}\text { Polydispersity } \\
\text { index }\end{array}$ \\
\hline PLA & 1020 & $-18 \pm 2$ & 0.387 \\
PLGA & $240-355$ & $-23 \pm 3$ & 0.337 \\
\hline
\end{tabular}

(PLA and PLGA) were used. The polymer particles were prepared with a O/W "oil in water" emulsion method. The results of the SEM analysis present two different types of nanostructures containing NIM: sphere-shaped nanoparticles (PLA) (Fig. 2) and nanofibers (PLGA) (Fig. 3). Detailed characteristics of the obtained nanostructures are given in Table 3. The presented results proved the unified structures of nanoparticles in both cases. The average size of nanoparticles (PLA) was about $1020 \mathrm{~nm}$ and the diameter of the nanofibers (PLGA) was about $240-355 \mathrm{~nm}$.

The release of the active ingredient from polymer nanoparticles is a rather complicated process. It can be affected by many factors such as the binding affinity between the polymer and the drug, polymer degradation speed, $\mathrm{pH}$ and so on.

b)

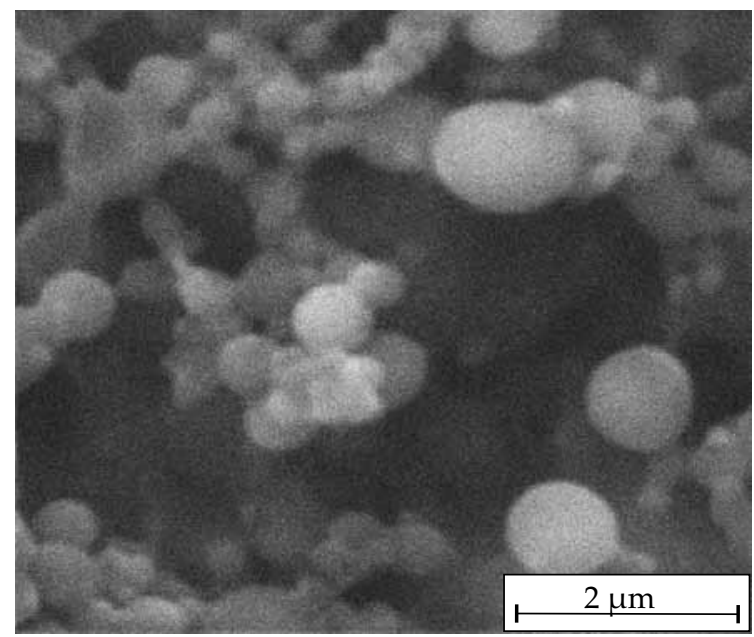

Fig. 2. Polymeric nanoparticles PLA loaded NIM: a) zoom 5000 times; b) zoom 20000 times

a)

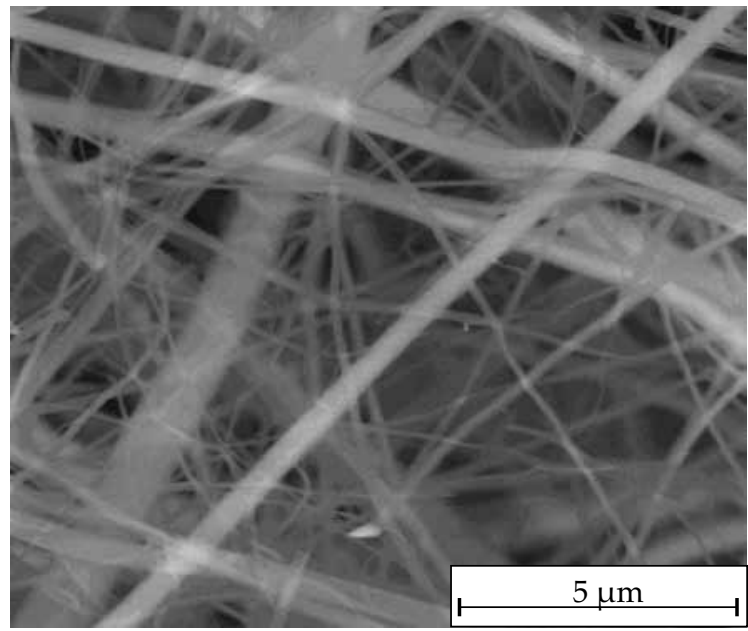

b)

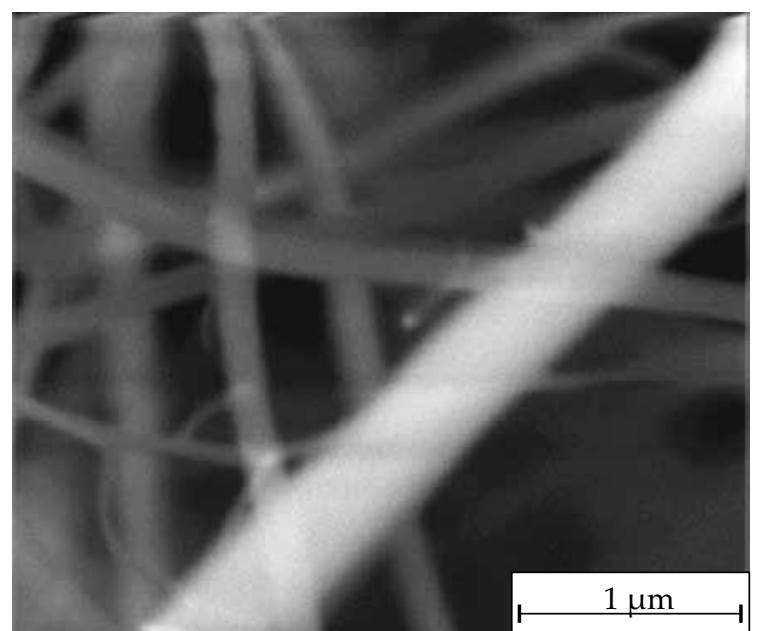

Fig. 3. Polymeric nanofibers PLGA loaded NIM: a) zoom 10000 times; b) zoom 40000 times 
The process of NIM release from polymer nanoparticles have been characterized and calculated for each experimental point by the active ingredient release ratio $-R R$ :

$$
R R=\left(\frac{n_{\mathrm{uw}}}{n_{\mathrm{zal}}}\right) \cdot 100 \%
$$

where: $n_{\mathrm{uw}}$ - number of active ingredient moles released from nanoparticles during the experiment at each point of time, $n_{\mathrm{zal}}-$ number of active ingredient moles loaded in nanoparticles at the beginning experiment.

The process of the NIM release from the polymer nanoparticles were investigated by the use of the DM method and the HTS method. The obtained results for different $\mathrm{pH}(\mathrm{pH}=2.5$ or 7.4 or 9.0$)$ and rpm speeds are presented from Fig. 4 to Fig. 8. We observed that, as in literature in the field, the active ingredient release depends on both $\mathrm{pH}$ (in both methods used) and the speed of shaking, rpm (in HTS method). The amount of released NIM from nanoparticles was greater in the same period of time with increased values of both $\mathrm{pH}$ and $\mathrm{rpm}$ (HTS method). For the faster shaking speed (300 rpm), in comparison with $100 \mathrm{rpm}$, the active ingredient release is greater by about $30 \%$ over slightly shorter times (see Fig. 4). For example, the release ratio changed after $5 \mathrm{~h}$ from $68 \%(100 \mathrm{rpm})$ to $90 \%(300 \mathrm{rpm})$ in the HTS method (PLA, $\mathrm{pH}=7.4$, see Fig. 4), the faster the shaking, the quicker the release. The comparison of NIM release from PLA nanoparticles at $\mathrm{pH}=7.4$ with the $\mathrm{DM}$ and the HTS methods is shown in Fig. 5 for the speed of shaking $300 \mathrm{rpm}$. As we can see, the release ratio is only slightly higher for the HTS method.

A comparison (Fig. 5 and Fig. 6) shows that there is only a small difference between the kinetics of NIM release in both methods used. In the case of both methods, higher $\mathrm{pH}$ values induce active ingredient release. The NIM release rate was greater for alkaline $\mathrm{pH}$ than neutral $\mathrm{pH}$, and the NIM release at neutral $\mathrm{pH}$ was greater than at acidic $\mathrm{pH}$. The lower active ingredient release rate at the acidic $\mathrm{pH}$ than alkaline $\mathrm{pH}$ is attributed to the repulsion between $\mathrm{H}^{+}$ions and cations on the surface of the polymers, which slows down the hydrolysis of the polymer. These results are also very important from the point of view of the scale change because they confirm the possibility of research performance in the micro-scale (HTS method) instead of the macro-scale (DM method). Moreover, the comparison of NIM release from the PLA and PLGA nanoparticles at $\mathrm{pH}=7.4,300 \mathrm{rpm}$, were done for both methods.

Further results are shown in Fig. 7 and Fig. 8. As we can see, the structure of the polymer has an impact on the process of drug release. The curves for PLA and PLGA release kinetics are very similar. A similar shape of curves for PLGA and PLA does not mean that the release is the same because sphere-shaped nanoparticles for PLA (Fig. 2) and nanofibers for PLGA (Fig. 3) were observed.

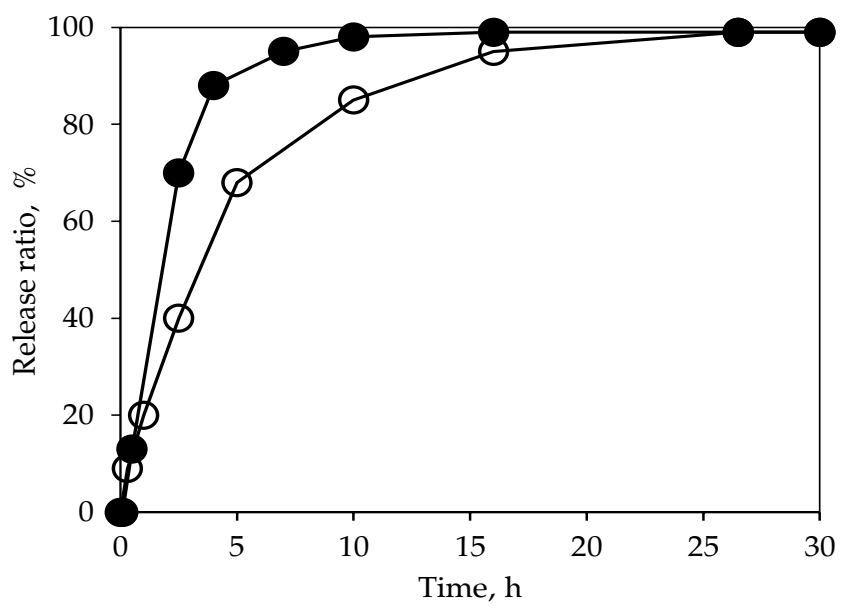

Fig. 4. The comparison of NIM release from PLA nanoparticles at $\mathrm{pH} 7.4$ with the HTS method, the speed of mixing $100 \mathrm{rpm}$ and $300 \mathrm{rpm}: \bullet 300 \mathrm{rpm}, \bigcirc 100 \mathrm{rpm}$

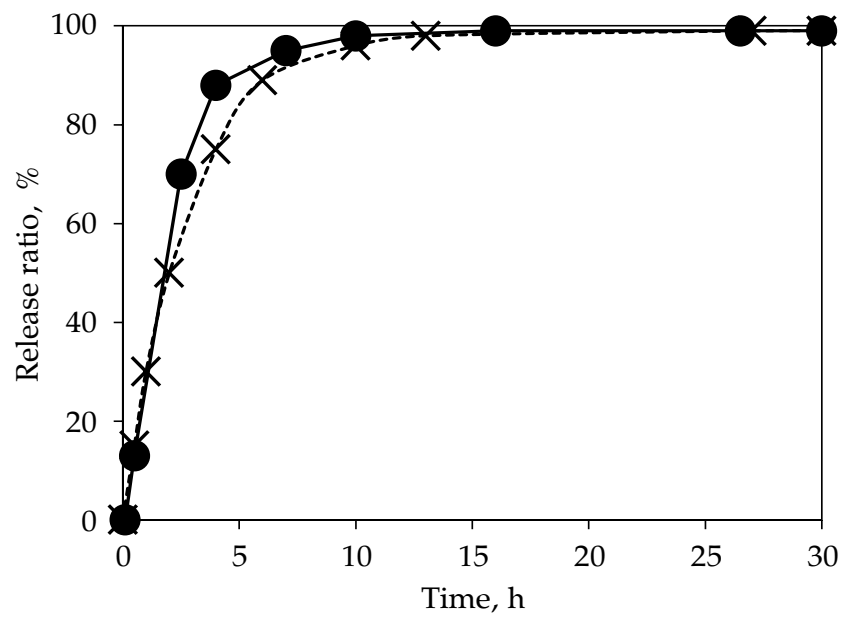

Fig. 5. The comparison of NIM release from PLA nanoparticles at $\mathrm{pH} 7.4$ with the DM and the HTS methods; the speed of mixing $300 \mathrm{rpm}: \bullet \mathrm{HTS}, \times \mathrm{DM}$; the line type corresponds to release study method as follows: dotted for DM method and solid for HTS method

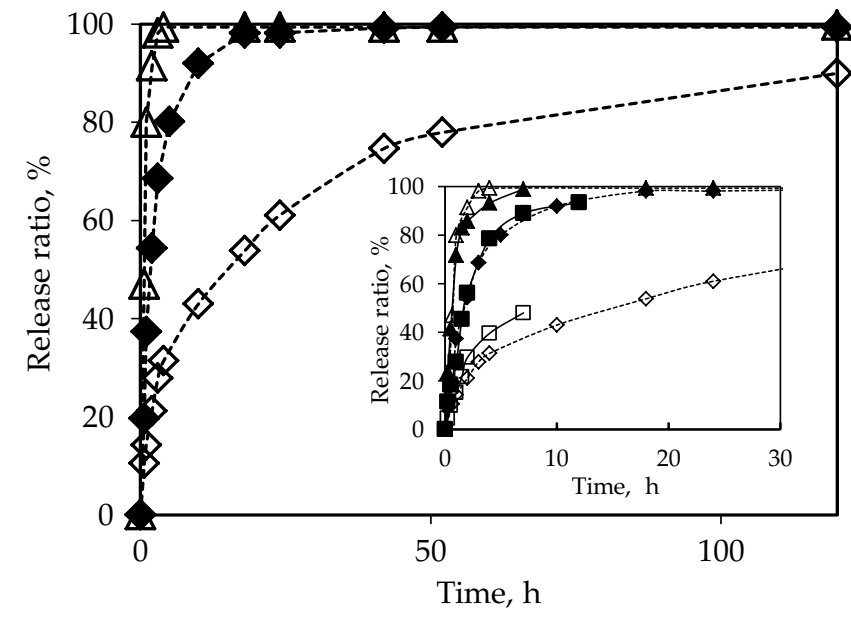

Fig. 6. The comparison of NIM release from PLGA nanoparticles at different $\mathrm{pH}$ with both the DM method, $300 \mathrm{rpm}: \diamond \mathrm{pH} 2.5$, $\diamond \mathrm{pH} 7.4, \triangle \mathrm{pH} 9.0$ and the HTS method: $\square \mathrm{pH} 2.5, \square \mathrm{pH} 7.4$, $\Delta \mathrm{pH}$ 9.0; the line type corresponds as in Fig. 5. 


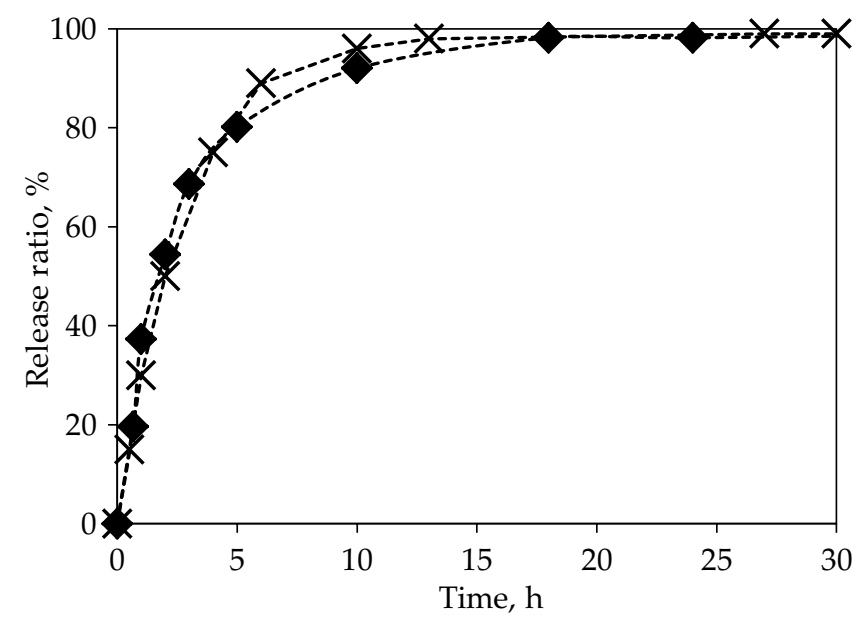

Fig. 7. The comparison of NIM release from PLA and PLGA nanoparticles at $\mathrm{pH} 7.4$ with the DM method, $300 \mathrm{rpm}$ : $\times$ PLA, $\diamond$ PLGA

The in vitro release of active ingredient-loaded nanoparticles was found to be first order [14]. A little faster NIM release (in particular period of time) was obtained for the use of PLA than of PLGA. This was slightly increased in PLA nanoparticles (99.0\%) in comparison with PLGA nanoparticles (93.5 \%) after $12 \mathrm{~h}$ (Fig. 8 ).

\section{CONCLUSIONS}

The wide investigation concerning NIM release from two types of polymer nanoparticles (PLA and PLGA) was done. The process of NIM release from polymer nanoparticles was investigated by the dialysis membrane method (DM) and high throughput screening method (HTS).

The comparison of the active ingredient release showed no significant differences between the two used methods for the initial period of release study (Fig. 5). However, NIM release depends on both $\mathrm{pH}$ (both used methods) and the speed of shaking (rpm in HTS method). The rate of NIM release is greater at higher $\mathrm{pH}$ (in both used methods) and faster rpm (HTS method).

Taking into consideration two scales of drug release experiment, obtained results give an important advantage, due to confirmation that the micro-scale (HTS method) experiment allows to obtain similar results as the macro-scale one (the DM method). Micro-scale, as a high-throughput, can be used for screening release ratio on initial periods of these studies consuming only small amounts of materials.

Understanding how to slow down the release of NIM from nanoparticles gives an advantage to drug delivery systems. Controlled release allows a decrease in the amount of delivered drug that still maintains an active concentration in human bodies in the frame of the therapeutic window.

Independently of the structure of the used polymers, the curves of the drug release are very similar. Faster

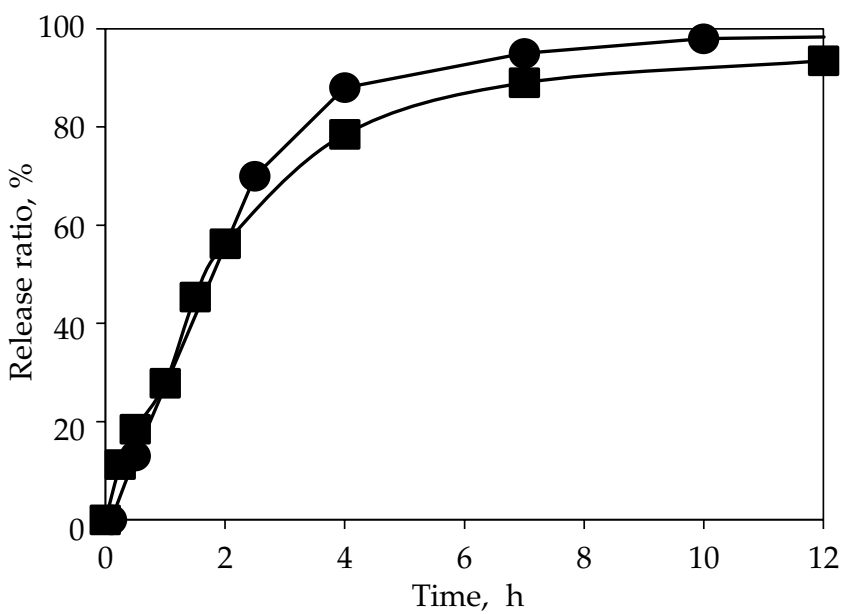

Fig. 8. The comparison of NIM release from PLA and PLGA nanoparticles at $\mathrm{pH} 7.4$ with the HTS method, $300 \mathrm{rpm}$ : • PLA, - PLGA

nimesulide release was obtained for the use of PLA over PLGA, which can be explained by the PLGA degradation in the used solution. The obtained results can bring the idea that the release process is not dependent on the polymer composition. But taking into consideration the difference between their nano-scale shapes (see Fig. 2 and Fig. 3) and the fact that PLGA polymer possesses the addition of glycolic acid in its' composition, it can be explained by different speeds of polymer hydrolysis nevertheless the process can be more complicated and a combination of other phenomena.

Funding for this research was provided by the Warsaw University of Technology, Warsaw, Poland.

\section{REFERENCES}

[1] Morigi V., Tocchio A., Pellegrini C.B. et al.: Journal of Drug Delivery 2012, 2012, 1. http://dx.doi.org/10.1155/2012/389485

[2] Nikalje A.P.: Medicinal Chemistry 2015, 5, 81. http://dx.doi.org/10.4172/2161-0444.1000247

[3] Bhowmik D., Bhattacharjee C., Margret C.R., Jayakar B.: Journal of Pharmaceutical Science and Technology 2009, 1, 20.

[4] Sahoo S.K., Parveen S., Panda J.J.: Nanomedicine 2007, 3, 20. http://dx.doi.org/10.1016/j.nano.2006.11.008

[5] Gunasekaran T., Haile T., Nigusse T., Dhanaraju M.D.: Asian Pacific Journal of Tropical Biomedicine 2014, 4, S1. http://dx.doi.org/10.12980/APJTB.4.2014C980

[6] Duggal D.: International Journal of Drug Development and Research 2011, 3, 4 .

[7] McInnes S.J.P., Michl T.D., Delalat B. et al.: ACS Applied Materials \& Interfaces 2016, 8, 4467. http://dx.doi.org/10.1021/acsami.5b12433

[8] Rainsford K.D.: Current Medical Research and Opinion 2006, 22, 1161.

https://doi.org/10.1185/030079906X104849 
[9] About Nimesulide [online]. http://bazalekow.mp.pl/leki/doctor_subst.html?id=608

[10] Debuigne F., Cuisenaire J., Jeunieau L. et al.: Journal de Pharmacie de Belgique 2000, 55, 59.

[11] Debuigne F., Cuisenaire J., Jeunieau L. et al.: Journal of Colloid and Interface Science 2001, 243, 90. https://doi.org/10.1006/jcis.2001.7879

[12] Ravikumara N.R., Madhusudhan B., Nagaraj T.S. et al.: Journal of Biomaterials Applications 2009, 24, 47. http://dx.doi.org/10.1177/0885328209103406

[13] Raffin R.P., Lima A., Lorenzoni R. et al.: Journal of Biomedical Nanotechnology 2012, 8, 309. http://dx.doi.org/10.1166/jbn.2012.1377

[14] Turk C.T., Oz U.C., Serim T.M., Hascicek C.: The American Association of Pharmaceutical Scientists 2014, 15, 161. http://dx.doi.org/10.1208/s12249-013-0048-9
[15] Bondi M., Azzolina A., Craparo E. et al.: Current Nanoscience 2009, 5, 39. http://dx.doi.org/10.2174/157341309787314575

[16] Sengel-Turk C.T., Hascicek C., Bakar F., Simsek E.: The American Association of Pharmaceutical Scientists 2017, $18,393$. http://dx.doi.org/10.1208/s12249-016-0514-2

[17] Mukesh D.: International Journal of Drug Development and Research 2012, 4, 40.

[18] Molavi O., Mahmud A., Hamdy S. et al.: Molecular Pharmaceutics 2010, 7, 364 . http://dx.doi.org/10.1021/mp900145g

[19] US Pat 20040156872 A1 (2004).

Received 16 X 2017.

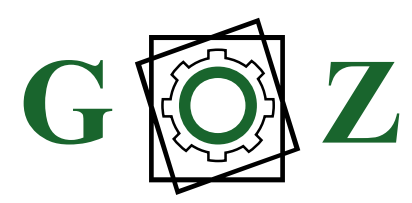

Polska Izba Opakowań i Międzynarodowe Targi Poznańskie zapraszają do udziału $\mathrm{w}$

IV Kongresie Przemysłu Opakowań

\section{„TRANSORMACJA PRZEMYSŁU OPAKOWAŃ W KIERUNKU GOSPODARKI O OBIEGU ZAMKNIĘTYM"}

Centrum Kongresowe MTP, Poznań - 2 października 2018 r.

Celem konferencji jest zainicjowanie zmian w projektowaniu i procesach wytwarzania opakowań, mających na celu zwiększenie odzysku surowców i materiałów z odpadów opakowaniowych i ponowne ich wykorzystanie.

Zaproszenie jest skierowane głównie do projektantów i producentów opakowań i materiałów opakowaniowych, a także do organizatorów i realizatorów procesów: zbiórki, selekcji i recyklingu opakowań.

\section{Informacje:}

biuro@pio.org.pl, info@pio.org.pl, tel. 226518394

Biuletyn Opakowaniowy, newsletter PIO

$$
\text { www.pakowanie.info, www.pio.org.pl }
$$

\section{Organizator}

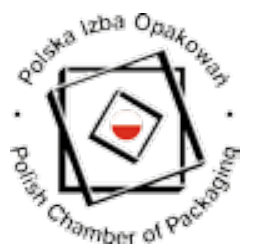

Gospodarz

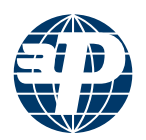

Międzynarodowe Targi Poznańskie 